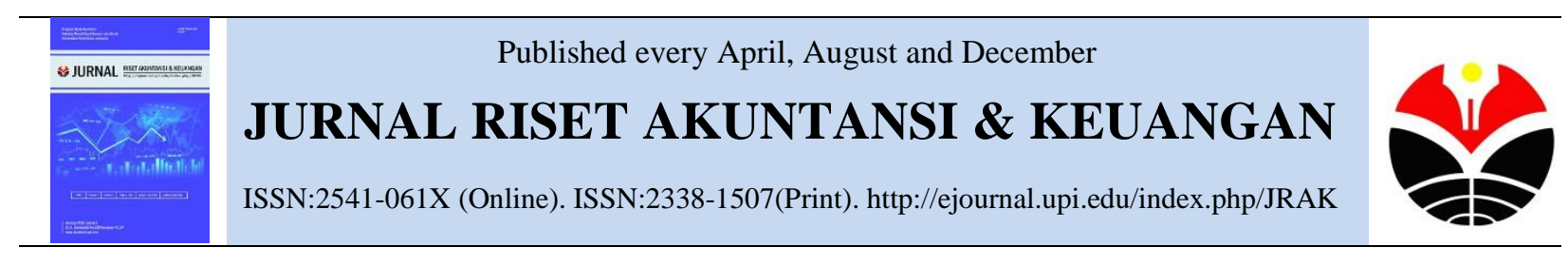

\title{
Rasio Profitabilitas, Rasio Leverage, dan Risiko Sistematis Terhadap Return Saham Pada Sektor Pertambangan
}

\author{
Yana Hendayana \\ Program Studi Akuntansi, Universitas Widyatama, Bandung, Indonesia
}

\begin{abstract}
The objective of this research is to investigate the effect of profitability ratio, leverage ratio and systematic risk to stock return of mining sector companies that listed in Indonesia Stock Exchange respectively consecutive years 2011-2015. Profitability Ratio is confirmed by Return on Equity, Leverage Ratio is confirmed by Debt Equity Ratio, Beta are calculated through Single Index Model. The sampling method used in this research is purposive sampling criteria: The Company is listed in Indonesia Stock Exchange on mining sector in the period 2011-2015. and the results are 14 companies according to the criteria of the sample. Pooling data method is used to collect the data and regression analysis as the analysis method. Leverage Ratio have significant effect on stock return, and systematic risk does not have significant effect on stock return.
\end{abstract}

Keywords: Leverage Ratio; Profitability Ratio; Stock Return; Systematic Risk.

Abstrak. Tujuan dari penelitian ini adalah untuk mengetahui pengaruh rasio profitabilitas, rasio leverage dan risiko sistematis terhadap return saham perusahaan sektor pertambangan yang tercatat di Bursa Efek Indonesia masing-masing berturut-turut tahun 2011-2015. Rasio Kemampuan Pengembangan dikonfirmasi dengan Return on Equity, Leverage Ratio Dikonfirmasi oleh Debt Equity Ratio, Beta dihitung melalui Single Index Model. Metode pengambilan sampel yang digunakan dalam penelitian ini adalah kriteria purposive sampling: Perusahaan terdaftar di Bursa Efek Indonesia pada sektor pertambangan periode 2011-2015. Dan hasilnya 14 perusahaan sesuai kriteria sampel. Metode pengumpulan data digunakan untuk mengumpulkan data dan analisis regresi sebagai metode analisis. Rasio Leverage berpengaruh signifikan terhadap return saham, dan risiko sistematis tidak berpengaruh signifikan terhadap return saham.

Kata Kunci: Rasio Leverage; Rasio Profitabilitas; Return Saham; Risiko Sistematis.

Corresponding author. Email: yana.hendayana@student.upi.edu. Jalan Cikutra No.204A, Sukapada, Cibeunying Kidul, Kota Bandung, Jawa Barat 40125

How to cite this article. Hendayana, Y. (2016). Rasio Profitabilitas, Rasio Leverage, dan Risiko Sistematis Terhadap Return Saham Pada Sektor Pertambangan. Jurnal Riset Akuntansi Dan Keuangan Program Studi Akuntansi Fakultas Pendidikan Ekonomi Dan Bisnis Universitas Pendidikan Indonesia, 4(3), $1177-1188$. Retrieved from http://ejournal.upi.edu/index.php/JRAK/article/view/4671

History of article. Received: September 2016, Revision: November 2016, Published: December 2016 Online ISSN: 2541-061X.Print ISSN: 2338-1507. DOI: 10.17509/jrak.v4i3.4671

Copyright@2016. Published by Jurnal Riset Akuntansi dan Keuangan. Program Studi Akuntansi. FPEB. UPI 


\section{PENDAHULUAN}

Investor harus mempertimbangkan risiko yang berkaitan dengan kepemilikan suatu saham. Investasi pada saham dinilai mempunyai tingkat risiko yang lebih besar dibandingkan dengan alternatif investasi lain seperti obligasi, deposito dan tabungan karena investasi pada saham bersifat tidak pasti. Risiko terbagi menjadi 2 bagian, yaitu risiko sistematis dan risiko tidak sistematis. Risiko sistematis adalah faktor-faktor risiko yang dapat mempengaruhi pasar secara menyeluruh. Risiko sistematis tidak dapat dihindari oleh para investor maupun perusahaan, karena risiko ini berkaitan dengan risiko pasar secara umum dan dampaknya akan berpengaruh terhadap semua perusahaan. Meskipun risiko sistematis ini sangat dipengaruhi oleh karakteristik pasar, tetapi risiko ini sangat sensitif terhadap faktor fundamental perusahaan.

Dalam literatur keuangan, risiko sistematis atau risiko pasar dapat dinyatakan dengan Beta. Beta suatu sekuritas menunjukan risiko sistematiknya yang tidak dapat didiversifikasi. Dengan demikian untuk kepentingan investasi, investor harus menaksir besarnya beta saham sebagai ukuran investasi di pasar modal.

Berdasarkan latar belakang diatas maka perumusan masalah dalam penelitian ini sebagai berikut: Bagaimana perkembangan
Rasio Profitabilitas, pada perusahaan sektor pertambangan yang terdaftar di Bursa Efek Indonesia periode 2011-2015; Bagaimana perkembangan Rasio Leverage, pada perusahaan sektor pertambangan yang terdaftar di Bursa Efek Indonesia periode 2011-2015; Bagaimana perkembangan Risiko Sistematis pada perusahaan sektor pertambangan yang terdaftar di Bursa Efek Indonesia periode 2011-2015; Bagaimana perkembangan Return Saham pada perusahaan sektor pertambangan yang terdaftar di Bursa Efek Indonesia periode 2011-2015.

Adapun tujuan penelitian adalah sebagai berikut: Bagi investor, penelitian ini diharapkan dapat menjadi sarana informasi dan evaluasi dalam keputusan investasi pada saham; Bagi perusahaan, penelitian ini diharapkan dapat menjadi acuan bagi manajemen perusahaan dalam memecahkan permasalahan yang ada dalam perusahaan dan menjadi pertimbangan dalam mengambil kebijakan keuangan; Bagi peneliti selanjutnya, penelitian ini diharapkan dapat menjadi bahan informasi dan referensi untuk mengkaji topik-topik yang berkaitan dengan masalah yang dibahas dalam penelitian ini.

\section{KAJIAN LITERATUR}

Peneliti Sebelumnya

\section{Tabel 1. Kajian Literatur Peneliti Sebelumnya.}

\begin{tabular}{clll}
\hline No & \multicolumn{1}{c}{ Nama Peneliti } & \multicolumn{1}{c}{ Judul } & \multicolumn{1}{c}{ Hasil Penelitian } \\
\hline 1. & Anas AL-Qudah, Mahmoud & The Effect of & Secara simultan Beta dan DER \\
Laham (Research Journal of & Financial & berpengaruh terhadap Return Saham. \\
Finance of Accounting Vol. & Leverage \& & Secara parsial DER berpengaruh \\
4, No.6, 2013) & Systematic Risk & terhadap Return Saham sedangkan \\
& on Stock Returns & Beta tidak berpengaruh terhadap \\
& in the Amman & Return Saham \\
& Stock Exchange & \\
& (Analytical Study & \\
& - Industrial & \\
& Sector) &
\end{tabular}


2. Tran Nha Ghi (International Journal of Information Research and Review Vol.2, Issue, 06, pp. 734-737, June, 2015)

The Impact of Capital Structure and Financial Performance on Stock Returns of The Firms in HOSE

3. Widya Retno Utami, Sri Hartoyo, Tubagus Nur Ahmad Maulana (Asian Journal of Business and Management Volume.03Issue05, October 2015)

4. Diah Ismayanti, Meina Wulansari Yusniar (Jurnal Wawasan Manajemen, Vol. 2, Nomor 1, Februari 2014)

5. Fariska Istanti Sumarsono, Khuzaini (Jurnal Ilmu Riset dan Manajemen: Volume 05, Nomor 1, Januari 2016)

6. Dwi Budi Prasetyo Supadi, M. Nuryatno Amin (Media Riset Akuntansi, Auditing, dan Informasi, Vol. 12, No.1, April 2012)

The Effect of Internal and External Factors on Stock Return: Empirical Indonesian Construction Subsector

Pengaruh Faktor Fundamental dan Resiko (Beta) terhadap Return Saham pada Perusahaan yang Termasuk Dalam Indeks LQ 45 Pengaruh Faktor Fundamental dan Risiko Sistematis terhadap Return di BEI

Pengaruh Faktor Fundamental dan terhadap Return Saham Syariah
Secara simultan ROE dan DER berpengaruh terhadap Return Saham. Secara parsial ROE dan DER berpengaruh terhadap Return Saham. Evidence from the

Secara simultan ROE, DER, dan Secara simultan ROE, DER, dan Saham Perbankan Risiko Sistematis
Secara simultan ROE dan DER berpengaruh terhadap Return Saham. Secara parsial ROE dan DER berpengaruh terhadap Return Saham. Saham. Secara parsial DER dan Beta berpengaruh terhadap Return Saham sedangkan ROE tidak berpengaruh terhadap Return Saham.

Beta berpengaruh terhadap Return Saham. Secara parsial ROE berpengaruh terhadap Return Saham sedangkan DER dan Beta tidak berpengaruh terhadap Return Saham Secara simultan ROE, DER, dan Beta tidak berpengaruh terhadap Return Saham. Secara parsial ROE, DER, dan Beta tidak berpengaruh terhadap Return Saham 


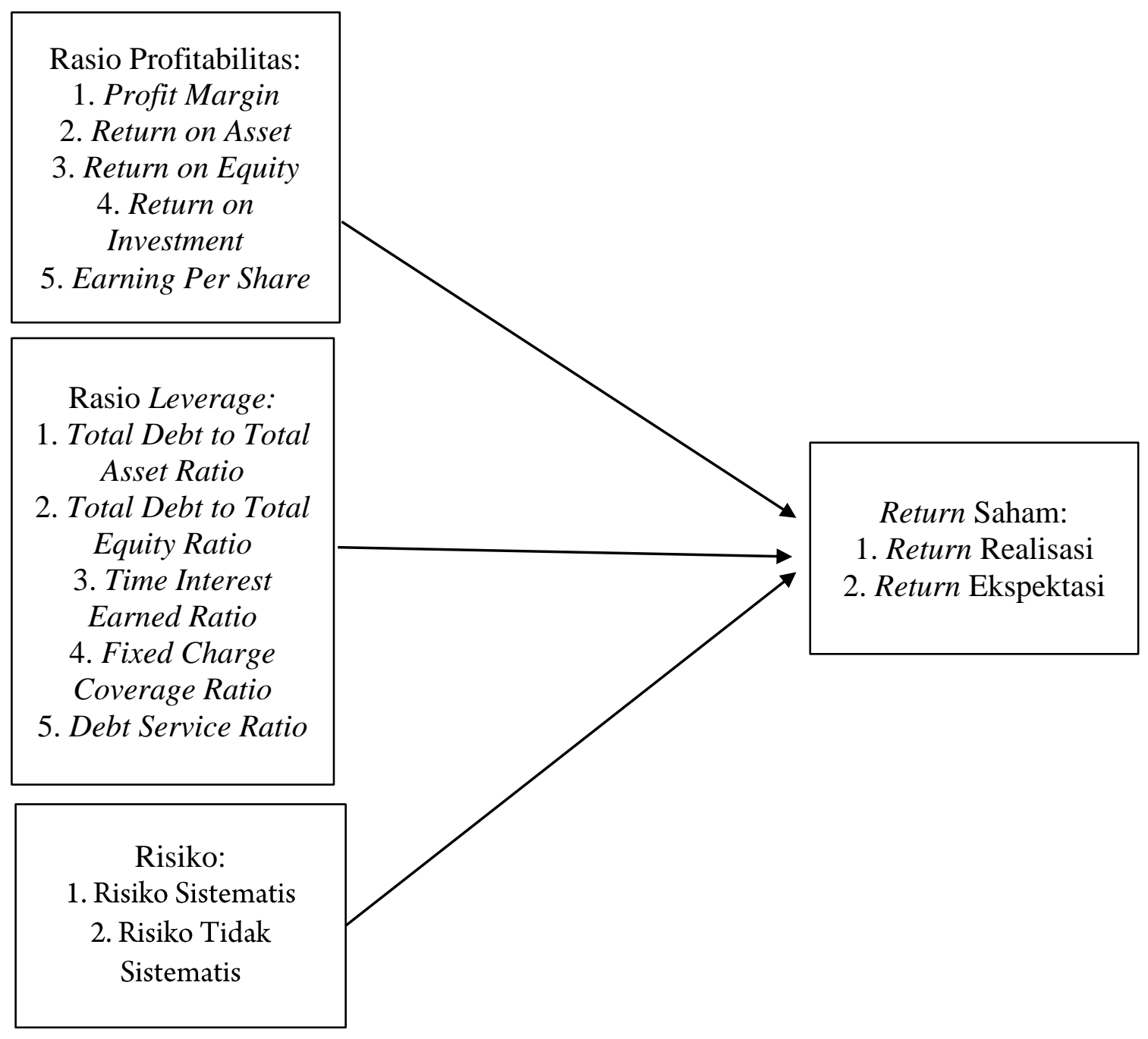

Gambar 1. Paradigma Penelitian 


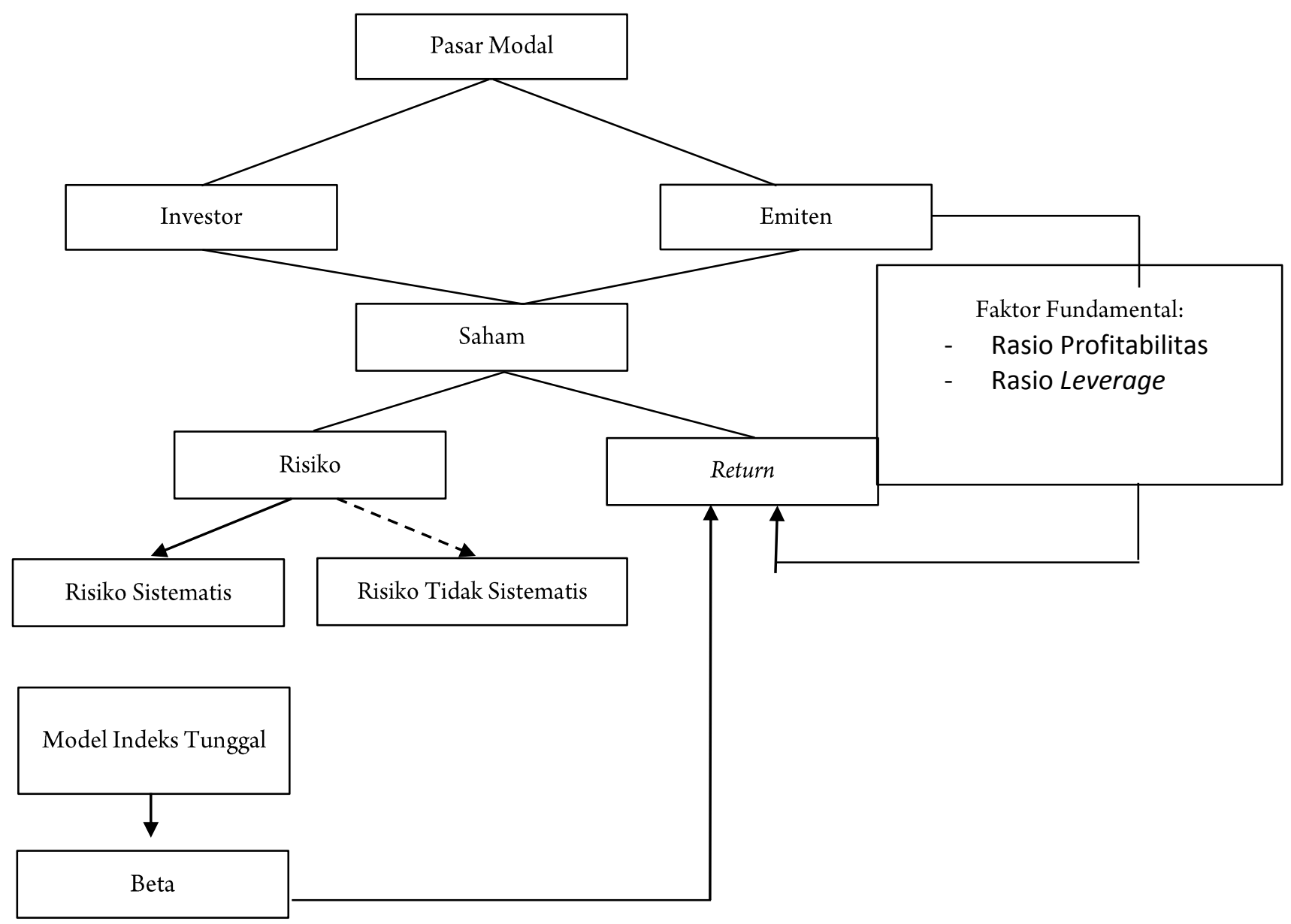

Yang diteliti

Yang tidak diteliti

\section{Gambar 2. Kerangka Pemikiran Penelitian}

Profitabilitas adalah kemampuan perusahaan memperoleh laba dalam hubungannya dengan penjualan, total aktiva maupun modal sendiri (R. Agus Sartono, 2010:122).

Tingkat leverage suatu perusahaan menunjukkan seberapa besar kebutuhan dana perusahaan dibelanjai dengan hutang (Sutrisno, 2012:217).

Menurut Sukardi (2010:255) risiko didefinisikan bahwa dalam konteks investasi, kondisi harm atau loss, dapat berupa kondisi dimana investor menerima keuntungan yang lebih kecil dari yang diisyaratkan.

\section{Hipotesis Penelitian}

Menurut Sugiyono (2014:183), hipotesis dilakukan untuk mengetahui diterima atau tidaknya hipotesis yang diajukan yang sekaligus merupakan tanda keberartian hubungan antara variabel-variabel yang kebenarannya harus diuji secara empiris. 
Hipotesis dapat dikatakan sebagai dugaan sementara yang perlu diketahui kebenarannya untuk membuktikan dugaan ini benar atau salah. Berdasarkan kerangka berfikir, maka hipotesis penelitian ini adalah: Terdapat perkembangan yang signifikan dari Rasio Profitabilitas terhadap Return Saham; Terdapat perkembangan yang signifikan dari Rasio Leverage terhadap Return Saham; Terdapat perkembangan yang signifikan dari Risiko Sistematis terhadap Return Saham.

\section{METODOLOGI PENELITIAN}

Jenis penelitian dalam penelitian ini adalah penelitian Eksplanasi Survey dengan metode penelitian deskriptif. Menurut Burhan Bungin (2013:46): Eksplanasi dimaksudkan untuk menjelaskan suatu generalisasi sampel terhadap populasinya atau menjelaskan hubungan, perbedaan atau pengaruh satu variabel dengan variabel yang lain.

Metode penelitian yang digunakan dalam penelitian ini adalah metode deskriptif. Menurut Nazir (2011:62) metode deskriptif adalah: Metode deskriptif adalah pencarian fakta dengan interpretasi yang tepat, dan merupakan suatu metode dalam meneliti status kelompok manusia, objek, suatu set kondisi, suatu sistem pemikiran, ataupun suatu kelas peristiwa pada masa sekarang.

Metode ini digunakan untuk menjawab permasalahan mengenai seluruh variabel penelitian secara independent. Metode ini digunakan untuk mencari informasi yang aktual, mengidentifikasi suatu masalah, melakukan pengujian hipotesis, serta memperoleh jawaban mengenai bagaimana hubungan dari hubungan suatu variabel terhadap variabel lain

Tabel 2 Sampel Penelitian

\begin{tabular}{ccc}
\hline No. & Kode Perusahaan & Nama Perusahaan \\
\hline 1. & ADRO & Adaro Energy Tbk. \\
2. & HRUM & Harum Energy Tbk. \\
3. & ITMG & Indo Tambangraya Megah Tbk. \\
4. & KKGI & Resource Alam Indonesia Tbk. \\
5. & PKPK & Perdana Karya Perkasa Tbk. \\
6. & PTBA & Petrosea Tbk. \\
7. & PTRO & Golden Eagle Energy Tbk. \\
8. & SMMT & Citatah Tbk. \\
9. & CTTH & Aneka Tambang (Persero) Tbk. \\
10. & ANTM & Vale Indonesia Tbk. \\
11. & INCO & Timah (Persero) Tbk. \\
12. & TINS & Medco Energi Internasional Tbk. \\
13. & MEDC & Radiant Utama Interinsco Tbk. \\
14. & RUIS &
\end{tabular}

Sumber: www.idx.co.id (2016)

\section{HASIL DAN PEMBAHASAN}

Perkembangan rasio Profitabilitas pada Perusahaan Sektor Pertambangan yang terdaftar di BEI periode 2011-2015 adalah sebagai berikut: 
Tabel 3. Perkembangan Rasio Profitabilitas Emiten

\begin{tabular}{ccccccc}
\hline & \multicolumn{5}{c}{ Tahun } & Rata-Rata \\
\cline { 2 - 6 } & $\mathbf{2 0 1 1}$ & $\mathbf{2 0 1 2}$ & $\mathbf{2 0 1 3}$ & $\mathbf{2 0 1 4}$ & $\mathbf{2 0 1 5}$ & $11 \%$ \\
ADRO & $23 \%$ & $13 \%$ & $7 \%$ & $6 \%$ & $5 \%$ & $19 \%$ \\
HRUM & $50 \%$ & $38 \%$ & $13 \%$ & $1 \%$ & $-6 \%$ & $30 \%$ \\
ITMG & $51 \%$ & $43 \%$ & $24 \%$ & $23 \%$ & $8 \%$ & $28 \%$ \\
KKGI & $69 \%$ & $32 \%$ & $24 \%$ & $11 \%$ & $7 \%$ & $-20 \%$ \\
PKPK & $-2 \%$ & $-5 \%$ & $0 \%$ & $-19 \%$ & $-74 \%$ & $28 \%$ \\
PTBA & $38 \%$ & $34 \%$ & $25 \%$ & $22 \%$ & $22 \%$ & $12 \%$ \\
PTRO & $33 \%$ & $26 \%$ & $9 \%$ & $1 \%$ & $-7 \%$ & $-3 \%$ \\
SMMT & $-9 \%$ & $3 \%$ & $4 \%$ & $-1 \%$ & $-15 \%$ & $1 \%$ \\
CTTH & $1 \%$ & $4 \%$ & $1 \%$ & $1 \%$ & $1 \%$ & $6 \%$ \\
ANTM & $18 \%$ & $23 \%$ & $3 \%$ & $-6 \%$ & $-8 \%$ & $7 \%$ \\
INCO & $19 \%$ & $4 \%$ & $2 \%$ & $10 \%$ & $3 \%$ & $11 \%$ \\
TINS & $20 \%$ & $9 \%$ & $11 \%$ & $15 \%$ & $2 \%$ & $-2 \%$ \\
MEDC & $10 \%$ & $2 \%$ & $2 \%$ & $1 \%$ & $-27 \%$ & $11 \%$ \\
RUIS & $2 \%$ & $12 \%$ & $11 \%$ & $18 \%$ & $12 \%$ & $10 \%$ \\
Rata-rata & $23 \%$ & $17 \%$ & $10 \%$ & $6 \%$ & $-6 \%$ & $30 \%$ \\
Max & $69 \%$ & $43 \%$ & $25 \%$ & $23 \%$ & $22 \%$ & $-20 \%$ \\
Min & $-9 \%$ & $-5 \%$ & $0 \%$ & $-19 \%$ & $-74 \%$ &
\end{tabular}

Sumber: data diolah (2016)

Perusahaan yang paling dominan dalam rasio profitabilitas pada perusahaan yang ada dalam sektor pertambangan ini adalah perusahaan ITMG yaitu PT. Indo Tambangraya Megah Tbk. dimana perusahaan ITMG ini memiliki rata-rata rasio profitabilitas sebesar $30 \%$ dimana nilai tersebut adalah nilai yang paling tinggi dalam 5 tahun terakhir dibanding dengan perusahaan lainnya.

Perkembangan Rasio Leverage pada Perusahaan Sektor Pertambangan yang terdaftar di BEI periode 2011-2015 adalah sebagai berikut:

Tabel 4. Perkembangan Rasio Leverage

\begin{tabular}{ccccccc}
\hline Emiten & $\mathbf{2 0 1 1}$ & $\mathbf{2 0 1 2}$ & $\mathbf{2 0 1 3}$ & $\mathbf{2 0 1 4}$ & $\mathbf{2 0 1 5}$ & Rata-rata \\
ADRO & $132 \%$ & $123 \%$ & $111 \%$ & $97 \%$ & $78 \%$ & $108 \%$ \\
HRUM & $31 \%$ & $26 \%$ & $22 \%$ & $23 \%$ & $11 \%$ & $22 \%$ \\
ITMG & $46 \%$ & $49 \%$ & $44 \%$ & $48 \%$ & $41 \%$ & $46 \%$ \\
KKGI & $49 \%$ & $42 \%$ & $45 \%$ & $44 \%$ & $28 \%$ & $41 \%$ \\
PKPK & $149 \%$ & $127 \%$ & $106 \%$ & $111 \%$ & $104 \%$ & $119 \%$ \\
PTBA & $41 \%$ & $50 \%$ & $55 \%$ & $74 \%$ & $82 \%$ & $60 \%$ \\
PTRO & $137 \%$ & $183 \%$ & $158 \%$ & $143 \%$ & $139 \%$ & $152 \%$ \\
SMMT & $150 \%$ & $8 \%$ & $3 \%$ & $58 \%$ & $79 \%$ & $60 \%$ \\
CTTH & $187 \%$ & $232 \%$ & $313 \%$ & $338 \%$ & $110 \%$ & $236 \%$ \\
ANTM & $41 \%$ & $54 \%$ & $71 \%$ & $83 \%$ & $66 \%$ & $63 \%$ \\
\hline
\end{tabular}




\begin{tabular}{crrrrrr}
\hline INCO & $37 \%$ & $36 \%$ & $33 \%$ & $31 \%$ & $25 \%$ & $32 \%$ \\
TINS & $43 \%$ & $34 \%$ & $61 \%$ & $119 \%$ & $73 \%$ & $66 \%$ \\
MEDC & $202 \%$ & $215 \%$ & $182 \%$ & $201 \%$ & $315 \%$ & $223 \%$ \\
RUIS & $365 \%$ & $392 \%$ & $388 \%$ & $317 \%$ & $223 \%$ & $337 \%$ \\
Rata-rata & $115 \%$ & $112 \%$ & $114 \%$ & $120 \%$ & $98 \%$ & $112 \%$ \\
Max & $365 \%$ & $392 \%$ & $388 \%$ & $338 \%$ & $315 \%$ & $337 \%$ \\
Min & $31 \%$ & $8 \%$ & $3 \%$ & $23 \%$ & $11 \%$ & $22 \%$ \\
\hline
\end{tabular}

Sumber: data idx.co.id yang diolah kembali (2016)

Perusahaan yang memiliki tingkat leverage tertinggi adalah perusahaan ADRO, PKPK, PTRO, CTTH, MEDC, dan RUIS yang artinya keenam perusahaan tersebut lebih banyak menggunakan hutang sebagai sumber dana perusahaan dibandingkan dengan modal sendiri.

Perkembangan Risiko Sistematis pada Perusahaan Sektor Pertambangan yang terdaftar di BEI periode 2011-2015 adalah sebagai berikut:

Tabel 5 Perkembangan Risiko Sistematis

\begin{tabular}{ccccccc}
\hline \multirow{2}{*}{ Emiten } & \multicolumn{5}{c}{ Tahun } & \multirow{2}{*}{ Rata-rata } \\
\cline { 2 - 5 } & $\mathbf{2 0 1 1}$ & $\mathbf{2 0 1 2}$ & $\mathbf{2 0 1 3}$ & $\mathbf{2 0 1 4}$ & $\mathbf{2 0 1 5}$ & \\
\hline ADRO & 1.69 & 1.49 & -1.22 & 1.23 & 0.92 & 0.82 \\
HRUM & 1.71 & 0.78 & -0.86 & 1.22 & 1.04 & 0.78 \\
ITMG & 1.52 & 1.26 & -0.83 & 0.96 & 0.36 & 0.65 \\
KKGI & 2.65 & 1.67 & 0.57 & 1.02 & -0.42 & 1.10 \\
PKPK & -0.83 & 4.83 & 1.83 & 1.65 & -0.07 & 1.48 \\
PTBA & 1.36 & 1.78 & -0.69 & 0.71 & 1.28 & 0.89 \\
PTRO & 1.47 & 1.61 & 0.38 & 1.98 & 1.57 & 1.40 \\
SMMT & 0 & 3.67 & -0.03 & 25.37 & 0.58 & 5.92 \\
CTTH & -0.35 & 0.37 & 1.09 & 0.12 & 0.94 & 0.43 \\
ANTM & 1.57 & 2.59 & 0.29 & 3.88 & -0.08 & 1.65 \\
INCO & 1.62 & 2.03 & -0.28 & 3.06 & 0.41 & 1.37 \\
TINS & 1.65 & 1.68 & -0.36 & 5.94 & 0.29 & 1.84 \\
MEDC & 0.76 & 0.82 & -0.63 & -0.46 & 0.18 & 0.13 \\
RUIS & 1.71 & 0.55 & 0.99 & 1.23 & 0.53 & 1.00 \\
Rata-rata & 1.18 & 1.80 & 0.02 & 3.42 & 0.54 & 1.39 \\
Max & 2.65 & 4.83 & 1.83 & 25.37 & 1.57 & 5.92 \\
Min & -0.83 & 0.37 & -1.22 & -0.46 & -0.42 & 0.13 \\
\hline
\end{tabular}

Sumber: data yahoofinance yang diolah kembali (2016)

Perusahaan yang paling dominan dalam risiko sistematis pada perusahaan yang ada dalam sektor pertambangan ini adalah perusahaan SMMT yaitu PT. Golden Eagle Energy Tbk. dimana perusahaan SMMT ini memiliki rata-rata risiko sistematis sebesar 5,92 dimana nilai tersebut adalah nilai yang paling tinggi dalam 5 tahun terakhir dibanding dengan perusahaan lainnya.

Perkembangan Return Saham pada Perusahaan Sektor Pertambangan yang terdaftar di BEI periode 2011-2015 adalah sebagai berikut: 
Tabel 6 Perkembangan Return Saham

\begin{tabular}{ccccccc}
\hline \multirow{2}{*}{ Emiten } & \multicolumn{5}{c}{ Tahun } & \multirow{2}{*}{ Rata-rata } \\
\cline { 2 - 5 } & $\mathbf{2 0 1 1}$ & $\mathbf{2 0 1 2}$ & $\mathbf{2 0 1 3}$ & $\mathbf{2 0 1 4}$ & $\mathbf{2 0 1 5}$ & $-25 \%$ \\
ADRO & $-31 \%$ & $-10 \%$ & $-31 \%$ & $-5 \%$ & $-50 \%$ & $-34 \%$ \\
HRUM & $-24 \%$ & $-12 \%$ & $-54 \%$ & $-40 \%$ & $-40 \%$ & $-31 \%$ \\
ITMG & $-24 \%$ & $8 \%$ & $-31 \%$ & $-46 \%$ & $-63 \%$ & $-16 \%$ \\
KKGI & $74 \%$ & $-62 \%$ & $-17 \%$ & $-51 \%$ & $-22 \%$ & $-12 \%$ \\
PKPK & $5 \%$ & $24 \%$ & $-62 \%$ & $2 \%$ & $-28 \%$ & $-22 \%$ \\
PTBA & $-24 \%$ & $-13 \%$ & $-32 \%$ & $23 \%$ & $-64 \%$ & $-25 \%$ \\
PTRO & $28 \%$ & $-60 \%$ & $-13 \%$ & $-20 \%$ & $-58 \%$ & $-27 \%$ \\
SMMT & $4 \%$ & $-1 \%$ & $10 \%$ & $-55 \%$ & $-90 \%$ & $-1 \%$ \\
CTTH & $-1 \%$ & $-18 \%$ & $10 \%$ & $5 \%$ & $-1 \%$ & $-27 \%$ \\
ANTM & $-34 \%$ & $-21 \%$ & $-15 \%$ & $-2 \%$ & $-65 \%$ & $-13 \%$ \\
INCO & $-34 \%$ & $-27 \%$ & $13 \%$ & $37 \%$ & $-55 \%$ & $-16 \%$ \\
TINS & $-39 \%$ & $-8 \%$ & $4 \%$ & $14 \%$ & $-51 \%$ & $3 \%$ \\
MEDC & $-28 \%$ & $-33 \%$ & $29 \%$ & $81 \%$ & $-32 \%$ & $2 \%$ \\
RUIS & $10 \%$ & $-11 \%$ & $-2 \%$ & $13 \%$ & $1 \%$ & $-17 \%$ \\
Rata-rata & $-9 \%$ & $-17 \%$ & $-14 \%$ & $-3 \%$ & $-44 \%$ & $3 \%$ \\
Max & $74 \%$ & $24 \%$ & $29 \%$ & $81 \%$ & $1 \%$ & $-34 \%$ \\
Min & $-39 \%$ & $-62 \%$ & $-62 \%$ & $-55 \%$ & $-90 \%$ & \\
\hline
\end{tabular}

Sumber: data yahoofinance yang diolah kembali (2016)

Perusahaan yang paling dominan dalam return saham pada perusahaan yang ada dalam sektor pertambangan ini adalah perusahaan MEDC yaitu PT. Medco Energi Internasional Tbk. dimana perusahaan MEDC ini memiliki rata-rata return saham sebesar $3 \%$ dimana nilai tersebut adalah nilai yang paling tinggi dalam 5 tahun terakhir dibanding dengan perusahaan lainnya.

\section{SIMPULAN}

Perkembangan Rasio Profitabilitas, Rasio Leverage, Risiko Sistematis, dan Return Saham Perusahaan Pertambangan yang Terdaftar di BEI Periode 2011-2015: Perkembangan Rasio Profitabilitas yang diproksikan dengan Return on Equity perusahaan-perusahaan sektor pertambangan mengalami penurunan tiap tahunnya selama periode 2011-2015. Hal ini diperlihatkan oleh nilai rata-rata dari tahun 2011 sampai 2015 dimana setiap tahunnya mengalami penurunan secara terus menerus, bahkan menginjak angka minus pada tahun 2015. Perusahaan yang paling dominan dalam rasio profitabilitas pada perusahaan yang ada dalam sektor pertambangan ini adalah perusahaan ITMG yaitu PT. Indo Tambangraya Megah Tbk dimana perusahaan ITMG ini memiliki rata-rata rasio profitabilitas sebesar $30 \%$. Sedangkan perusahaan yang memiliki ratarata nilai rasio profitabilitas yang paling rendah adalah perusahaan PKPK yaitu PT. Perdana Karya Perkasa Tbk. yang memiliki rata-rata rasio profitabilitas sebesar $-20 \%$. Faktor anjloknya harga-harga komoditas barang pertambangan dan adanya regulasi pemerintah mengenai ketentuan ekspor inilah yang kemungkinan mengakibatkan turunnya tingkat profitabilitas perusahaan-perusahaan pertambangan ini; Perkembangan Rasio Leverage yang diproksikan dengan Debt to Equity Ratio perusahaan-perusahaan sektor 
pertambangan berfluktuasi dari tahun 20112015. Tingkat rata-rata tertinggi rasio leverage ini ada pada tahun 2014, sedangkan rata-rata terendahnya ada pada tahun 2015. Perusahaan yang paling dominan dalam rasio leverage pada perusahaan yang ada dalam sektor pertambangan ini adalah perusahaan RUIS yaitu PT. Radiant Utama Interinsco Tbk. dimana perusahaan RUIS ini memiliki rata-rata rasio leverage sebesar $337 \%$. Sedangkan perusahaan yang memiliki ratarata nilai rasio leverage yang paling rendah adalah perusahaan HRUM yaitu PT. Harum Energy Tbk. yang memiliki rata-rata rasio leverage sebesar $22 \%$. Mayoritas perusahaan pertambangan telah berhasil untuk sedikit mengurangi hutang pada tahun 2015, namun rasio hutang memasuki tingkat tertinggi pada tahun 2014 dan kas yang digunakan untuk membayar hutang sama besarnya dengan kas yang diterima dari pinjaman. Karena adanya kondisi tersebut sehingga lembaga pemeringkat kredit merespon hal ini dengan penurunan peringkat kredit perusahaan pertambangan; Perkembangan Risiko Sistematis yang diproksikan dengan Beta perusahaan-perusahaan sektor pertambangan mengalami fluktuasi pada tahun 2011-2015. Nilai beta terendah ada pada tahun 2013 sebesar 0,02 yang berarti tingkat risiko pada tahun 2013 adalah rendah, sedangkan nilai beta tertinggi ada pada tahun 2014 sebesar 3,42 yang berarti tingkat risiko pada tahun 2014 adalah tinggi. Perusahaan yang paling dominan dalam risiko sistematis pada perusahaan yang ada dalam sektor pertambangan ini adalah perusahaan SMMT yaitu PT. Golden Eagle Energy Tbk. dimana perusahaan SMMT ini memiliki rata-rata risiko sistematis sebesar 5,92. Sedangkan perusahaan yang memiliki rata-rata nilai risiko sistematis yang paling rendah adalah perusahaan MEDC yaitu PT. Medco Energi Internasional Tbk. yang memiliki rata-rata risiko sistematis sebesar 0,13 . Seperti yang diketahui bahwa pada tahun 2014 di Indonesia diadakan pemilihan presiden baru yang berarti adanya reformasi pemerintahan oleh presiden yang baru. Dengan adanya situasi ini, maka dapat terjadi gangguan politik terhadap keadaan perekonomian di Indonesia itu sendiri. Kondisi ini kemungkinan dapat menjadi alasan tingkat risiko yang tinggi pada tahun 2014 pada perusahaan-perusahaan sektor pertambangan ini; Perkembangan Return Saham perusahaan-perusahaan sektor pertambangan mengalami fluktuasi pada tahun 2011-2015. Return Saham rata-rata perusahaan sektor pertambangan ini memiliki nilai negatif setiap tahunnya dari tahun 2011 sampai 2015 yang berarti rata-rata perusahaan tidak dapat memberikan pengembalian atas investasi yang dilakukan oleh investor. Ratarata tertinggi return saham perusahaan sektor pertambangan ada pada tahun 2014, sedangkan rata-rata terendah return saham ada pada tahun 2015. Perusahaan yang paling dominan dalam return saham pada perusahaan yang ada dalam sektor pertambangan ini adalah perusahaan MEDC yaitu PT. Medco Energi Internasional Tbk. dimana perusahaan MEDC ini memiliki rata-rata return saham sebesar 3\%. Sedangkan perusahaan yang memiliki rata-rata return saham yang paling rendah adalah perusahaan HRUM yaitu PT. Harum Energy Tbk. yang memiliki rata-rata return saham sebesar $-34 \%$.

\section{DAFTAR PUSTAKA}

Anas Al-Qudah, Mahmoud Laham. 2013. Research Journal of Finance of Accounting 4(6).

Al-Qudah, Anas. Laham, Mahmoud. 2013. The Effect of Financial Leverage \& Systematic Risk on Stock Returns in the Amman Stock Exchange (Analytical Study - Industrial Sector). Research Journal of Finance of Accounting: 4(6).

Bungin, Burhan. 2013. Metodologi Penelitian Kuantitatif: Komunikasi, Ekonomi, dan Kebijakan Publik serta Ilmu-Ilmu Sosial Lainnya. Edisi Kedua. Jakarta : Kencana.

Diah Ismayanti, Meina Wulansari Yusniar. 2014. Jurnal Wawasan Manajemen, 2(1). 
Dwi Budi Prasetyo Supadi, M. Nuryatno Amin. 2012. Media Riset Akuntansi, Auditing, dan Informasi, 12(1).

Fahmi, Irham. 2013. Analisis Laporan Keuangan. Bandung: Alfabeta.

Fariska Istanti Sumarsono, Khuzaini. 2016. Jurnal Ilmu Riset dan Manajemen: 5(1).

Ghi, Tran Nha. 2015. The Impact of Capital Structure and Financial Performance on Stock Returns of The Firms in HOSE. International Journal of Information Research and Review. 2(6). pp. 734-737.

Ginting, Suriani. Erward. 2013. Analisis Faktor-Faktor yang Mempengaruhi Return Saham pada Perusahaan Manufaktur yang Terdaftar di Bursa Efek Indonesia. Jurnal Wira Ekonomi Mikroskill. 3(1).

Hanafi, Mamduh M. Halim, Abdul. 2012. Analisis Laporan Keuangan. Edisi Keempat. Yogyakarta : UPP STIM YKPN.

Hartono, Jogiyanto. 2013. Teori Portofolio dan Analisis Investasi. Edisi Kedelapan. Yogyakarta : BPFE.

Ismayanti, Diah. Yusniar, Meina Wulansari. 2014. Pengaruh Faktor Fundamental dan Risiko (Beta) Terhadap Return Saham pada Perusahaan yang Termasuk Dalam Indeks LQ 45. Jurnal Wawasan Manajemen. 2(1).

Kasmir. 2015. Analisis Laporan Keuangan. Jakarta : PT. Raja Grafindo Persada.

Kasmir dan Jakfar. 2012. Studi Kelayakan Bisnis. Edisi Revisi. Jakarta: Kencana.

Martalena, dan Malinda. 2011. Pengantar Pasar Modal. Edisi Pertama. Yogyakarta : Andi.

Nazir. 2011. Metode Penelitian. Cetakan keenam. Bogor : Ghalia Indonesia.

Noor, Juliansyah. 2014. Metodologi Penelitian: Penelitian, Tesis, Disertasi dan Karya Ilmiah. Edisi Pertama. Jakarta : Kencana.

Sartono, Agus. 2010. Manajemen Keuangan Teori dan Aplikasi. Edisi Keempat. Yogyakarta : BPFE.
Sugiyono. 2014. Metode Penelitian Manajemen. Bandung : Alfabeta.

Sukardi, David. Indonanjaya, Kurniawan. 2010. Manajemen Investasi: Pendekatan Teknikal dan Fundamental Untuk Analisis Saham. Edisi Pertama. Yogyakarta : Graha Ilmu.

Sumarsono, Fariska Istanti. Khuzaini. 2016. Pengaruh Faktor Fundamental dan Risiko Sitematis Terhadap Return Saham Perbankan di BEI. Jurnal Ilmu dan Riset Manajemen. 5(1).

Supadi, Dwi Budi Prasetyo. Amin, M. Nuryatno. 2012. Pengaruh Faktor Fundamental dan Risiko Sistematis Terhadap Return Saham Syariah. Media Riset Akuntansi, Auditing dan Informasi. 12(1).

Sutrisno. 2012. Manajemen Keuangan: Teori, Konsep dan Aplikasi. Cetakan kedelapan. Yogyakarta : Ekonisia.

Tandelilin, Eduardus. 2010. Teori Portofolio dan Investasi. Edisi Pertama. Yogyakarta : Graha Ilmu.

Tran Nha Ghi. 2015. International Journal of Information Research and Review. 2(6). pp. 734-737.

Undang-Undang Tahun 1995 tentang Pasar Modal.

Utami, Widya Retno. Hartoyo, Sri. Maulana, Tubagus Nur Ahmad. 2015. The Effect of Internal and External Factors on Stock Return: Empirical Evidence from the Indonesian Construction Subsector. Asian Journal of Business and Management. 3(5).

Wibowo, Agung Edy. 2012. Aplikasi Praktis SPSS dalam Penelitian. Edisi Kedua. Yogyakarta : Gava Media.

Widya Retno Utami, Sri Hartoyo, Tubagus Nur Ahmad Maulana. 2015. Asian Journal of Business and Management. 3(5).

Yusuf, A. Muri. 2014. Metode Penelitian:

Kuantitatif, Kualitatif, dan Penelitian

Gabungan. Edisi Pertama. Jakarta : Kencana. 


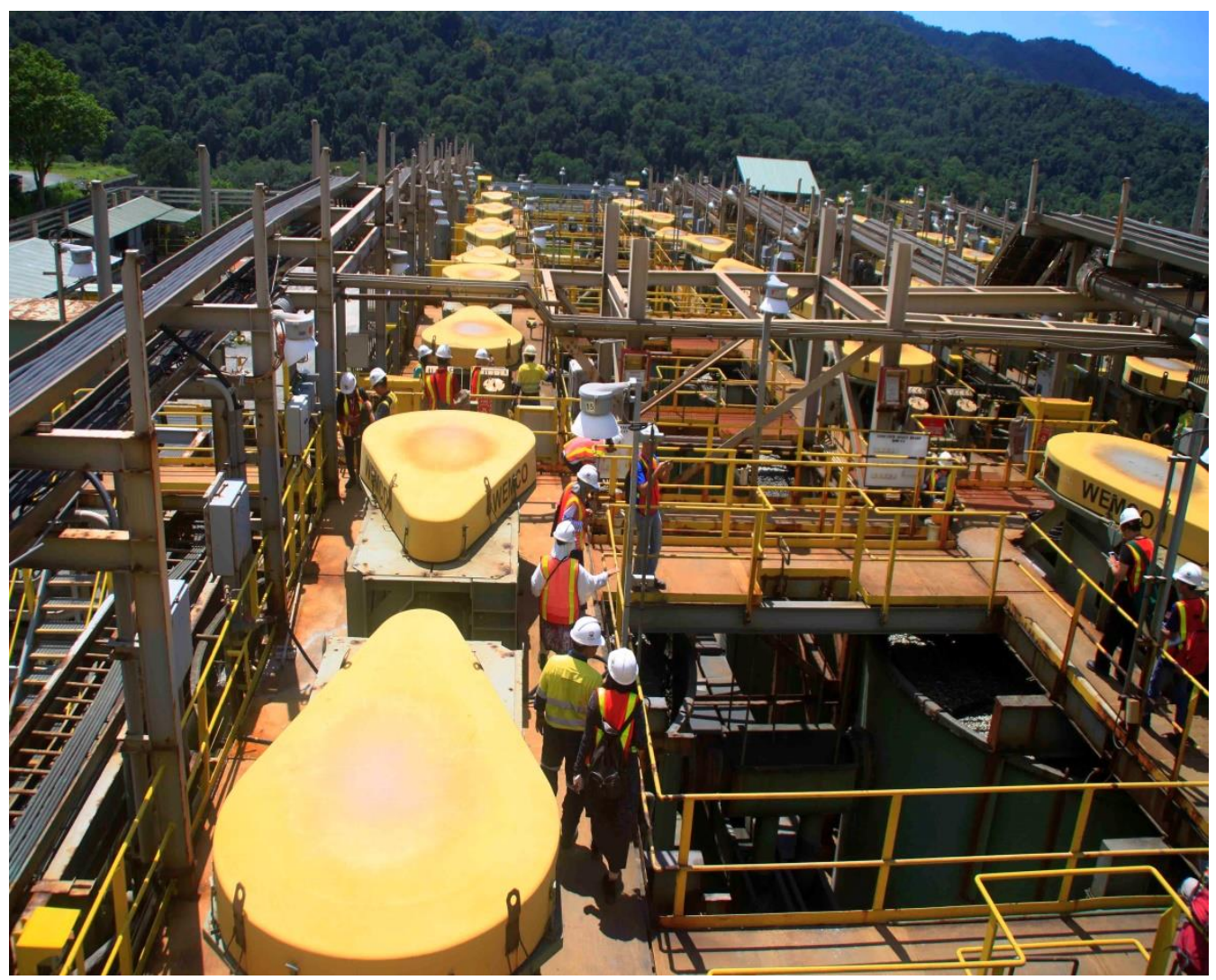

http://adhikurniawan.com/wp-content/uploads/2016/02/smb3_07.jpg

Kegiatan Karyawan di PT Newmont dari mulai kegiatan processing sebagai tahapan awal dari proses pengolahan bijih yang ditambang oleh PT Newmont sampai kegiatan PT Newmont dalam membangun instalasi pipa 